\title{
SCALABILITY OF E-COMMERCE IN THE COVID-19 ERA
}

\author{
Sahana Dinesh ${ }^{*}{ }^{\square}$ iD, Dr. Y. MuniRaju 2 \\ ${ }^{* 1}$ Research Scholar (UGC-SRF), Department of Commerce, Mangalore University, \\ Mangalagangothri, Karnataka, India \\ 2 Professor, Department of Commerce, Mangalore University, Mangalagangothri, Karnataka, India
}

DOI: https://doi.org/10.29121/granthaalayah.v9.i1.2021.3032

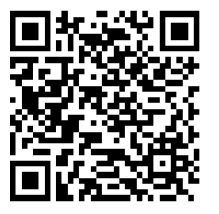

\section{Article Type: Research Article}

Article Citation: Sahana Dinesh, and Dr. Y. MuniRaju. (2021).

SCALABILITY OF E-COMMERCE IN THE COVID-19 ERA. International Journal of Research -

GRANTHAALAYAH, 9(1), 123-128.

https://doi.org/10.29121/granthaa

layah.v9.11.2021.3032

Received Date: 28 December 2020

Accepted Date: 30 January 2021

Keywords:

COVID-19

E-Commerce

Customer Engagement

Co-Opetition

\section{ABSTRACT}

The COVID-19 pandemic has had major influence on the people all over the world. This has also influenced the consumers to shop online owing to their apprehensions regarding the safety. Therefore, this has opened up huge opportunities to online retailers and platforms to increase their sales and revenue and at the same time posed several challenges. Ecommerce business is becoming scalable as more and more people are forced to buy online due to their apprehension to go to physical stores in the time of pandemic. This study is aimed at understanding the factors that are causing an increase in the e-commerce transactions and also attempts to know the consumer behaviour during the COVID- 19 pandemic. Through a survey of 195 respondents, the study found that frequency of online shopping has increased during the pandemic period. The study suggests that both online and offline retailers have to invest in smarter technologies and improve customer engagement.

\section{INTRODUCTION}

The COVID-19 pandemic has changed the life of people world over. Lockdowns and social distancing norms have had a major influence over the way people shop. Consumers are looking for a convenient and safer place to do their shopping. The footfalls at the shopping malls have also reduced post-lockdown and this can be due to the hesitancy among the consumers to shop in these locations. Hence, online shopping is gaining further significance in the time of pandemic. The Indian e-commerce companies have also seemed to have taken this as an opportunity to serve the existing customers who already shop online as well as to attract new customers who otherwise would shop from offline retail stores. In 2016-17, online retail market in India was just 1.5 percent of the overall retail market (IBEF, May 2018). With the pandemic haunting the people in the years to come, e-commerce market can be expected to witness a drastic change.

The pandemic has caused an increase in the number of customers shopping online and also the number of firsttime users of e-commerce has also raised (Halan, 2020). A survey by UNCTAD (2020) also found that the pandemic has resulted in a sales growth of e-commerce websites. The survey found that around 64 per cent of third-party marketplaces have witnessed an increase in their sales during the period March and July 2020. Bain \& Co Report (2020) indicated that due to customers look for safety and convenience, significance of e-commerce would enhance in the post-pandemic period and could reach 300 to 350 million shoppers by the Financial year 2025 .

(C) 2021 The Author(s). This is an open access article distributed under the terms of the Creative Commons Attribution License, which permits unrestricted use, distribution, and reproduction in any medium, provided the original author and source are credited. 
Scalability of E-Commerce in The Covid-19 Era

The present study aims at understanding the factors that would help e-commerce companies to scale-up their business during and after the pandemic. Further, as the reports suggest that the customers are increasingly shifting their purchases to online sites during the pandemic, this study also aims at knowing the customer behaviour during the pandemic.

\subsection{OBJECTIVES}

The study was conducted with the purpose of understanding the factors that assist e-commerce companies to enhance their business during the pandemic. Therefore, the study was undertaken with the following objectives:

1) To know the scalability factors in e-commerce business during COVID-19.

2) To understand the online customer behaviour during COVID-19.

3) To suggest the suitable e-commerce strategies to enhance customer experience.

\section{MATERIALS AND METHODS}

This study is exploratory in nature and is aimed at knowing the changes that are being witnessed in the ecommerce segment of the country during the COVID- 19 pandemic. For this purpose, we have sourced the data from industry reports, news articles and various websites. The study highlights the opportunities and challenges for online retailers during the pandemic. Further, data was also collected from the customers. For this purpose, questionnaires were administered and data was collected from a sample of 195 respondents residing in Mysore division of Karnataka State using the convenience sampling method. The collected data was analysed using the descriptive statistical tools. For the purpose of data analysis IBM SPSS 20.0 version was used.

\section{SCALABILITY FACTORS FOR ONLINE RETAILERS DURING COVID-19}

The following are the factors that have enabled e-commerce companies to enhance their business during the pandemic.

1) Emergence of demand for new category: Mobile phones were the biggest contributor to online sales in the year 2019 (IBEF, June 2020). Also, the share of consumer electronics and apparels was highest in ecommerce retail. However, COVID-19 crisis has led to a situation where customers are now looking to buy necessities and groceries online. Online shopping service for grocery is not available to all pincodes in the country. Hence, the online retailers can find this opportunity to cater to the emerging needs of customers.

2) Increasing sales: The Bain \& Company report 2020 has noted that the online market in the country would expand from 300 to 350 million shoppers in the next 5 years and also the Gross Merchandise Value would be pushed to $\$ 100$ to $\$ 120$ billion by 2025 . This shows that an amazing opportunity lies for online retailers to expand their sales in the coming years. As more customers will gradually start favouring online stores for purchasing food, groceries, personal care and health care products apart from consumer electronics and fashion, e-commerce retailers will have to cater to the rising customer demand.

3) Local partnerships and co-existence: It are very unlikely that offline retailers could completely replace their offline counterparts in countries like India. However, online retailers can take the present situation as an opportunity to partner with offline retailers located in tier- 2 cities and beyond to increase their customer touch-points. Partnering with small and local retailers to act as pick-up stores can help online retailers to expand their market. Also, the offline retailers can increase their footfalls due to this. In this new era, coexistence of online and offline stores is vital. One of the leading e-commerce platforms in the country, Amazon India, has launched a program called 'Local Shops on Amazon' where local sellers can register on Amazon and serve more customers from local areas (Amazon Services, n.d). Many shopkeepers across the country have registered for this program and have added a wide range of products to the already large product assortment of Amazon. The products range from consumer electronics to durables, kitchen items to grocery and consumables, gifts, fresh flowers and cakes. This enables them to boost their sales. Another e-commerce player Flipkart has also partnered with many kirana stores with similar objectives.

4) Customer loyalty: Increasing online sales during a pandemic is not an absolute measure of success for online retailers. Instead, online platforms have to focus on increasing customer engagement with the online 
stores. Retaining the new customers can contribute to online retailers' profits in the long run. In this direction, online retailers along with their core activities can provide sticky customer services such as video streaming, gaming, booking and payments in a single platform. (Poojary \& Krishna, 2020)

\section{CHALLENGES FOR ONLINE RETAILERS DUE TO COVID-19}

Though the opportunities are many to improve scalability during extreme conditions, the online retailers also have to address equally challenging issues to meet the increasing customer orders. The following are some of the challenges posed to online retailers due to COVID-19.

1) Development of infrastructure: With the increase in demand online retailers have to improve their infrastructure as well. Supply chain has to be improved to a great extent to ensure customer satisfaction. Online retailers will also have to strengthen their relationships with local retailers to provide services beyond the tier- 2 cities.

2) Concerns over quality: As more customers are being attracted towards online stores, compromise over quality is something which is not affordable to online stores. Online stores will have to undertake more stringent quality checks to ensure quality products reach the customers. This can go a long way in ensuring success to online retailers

3) Co-opetition: In no way online retailing can dominate offline retailing or vice-versa. Co-existence is the only way to remain relevant in the ever-changing business world. Online retailers should partner with local retailers to enlarge their reach. There is growing annoyance between online and offline retailers in India. In such a scenario, competition between the two has to be replaced by co-operation which would ultimately benefit the customers.

4) Social influence: The community is going to be a great influencer for customers to shop online. Hence, online retailers have to work towards engaging the community through social commerce. The marketing strategies of online retailers have to involve the customers to promote the online retailer.

5) Increase customer mindshare: It is vital for the online retailers to retain the customers for a long run. They have to invest more in sticky customer services. Providing services like video streaming, gaming, booking and payments in a single platform along with providing their core services can increase customer engagement with the platform.

Addressing these challenges effectively would ensure long run success to online retailers and assist them in scaling their operations.

\section{RESULTS AND DISCUSSION}

This section gives the demographic profile of the respondents and their online shopping behaviour during COVID-19.

Table 1: Profile of the respondents

\begin{tabular}{|c|c|c|}
\hline Particulars & Frequency (N=195) & Percentage \\
\hline Gender: & 92 & \\
Male & 103 & 47.2 \\
Female & & 52.8 \\
\hline Age (in years): & 32 & \\
Up to 25 & 65 & 16.4 \\
$26-35$ & 40 & 33.3 \\
36-45 & 44 & 20.5 \\
$46-55$ & 14 & 22.6 \\
55 and above & & 7.2 \\
\hline Educational Level: & 15 & 7.7 \\
Up to 12th Standard & 93 & 47.7 \\
Graduate &
\end{tabular}

International Journal of Research -GRANTHAALAYAH 
Scalability of E-Commerce in The Covid-19 Era

\begin{tabular}{|c|c|c|}
\hline Post Graduate & 81 & 41.5 \\
Other & 06 & 3.1 \\
\hline Occupation: & 75 & 38.5 \\
Employed in a Government Job & 106 & 54.4 \\
Employed in a Private Job & 14 & 7.2 \\
\hline Self-Employed & & \\
Monthly Income (in INR): & 18 & 9.2 \\
Below 20000 & 37 & 19.0 \\
20001-30000 & 58 & 29.7 \\
30001-40000 & 61 & 31.3 \\
40001-50000 & 21 & 10.8 \\
Above 50000 & & \\
Marital Status: & 134 & 68.7 \\
Married & 61 & 31.3 \\
\hline Unmarried & & \\
\hline
\end{tabular}

Source: Survey Data

Table 1 show that the majority of respondents are female and are in the age group of 26-35. All the respondents are well educated and are employed with more than a half being employed in private jobs. Majority of the respondents have a better income level and are married. The analysis of the respondent's profile reveals that they are well educated and have an independent source of income. They are able to make purchase decisions independently.

Table 2: Online Buying Behaviour

\begin{tabular}{|c|c|c|c|}
\hline \multicolumn{2}{|c|}{ Particulars } & Frequency & Percentage \\
\hline Shopped online before pandemic & Yes & 153 & 78.5 \\
& No & 42 & 21.5 \\
& Total & 195 & \\
\hline Shopped online during pandemic & Yes & 180 & 92.3 \\
& No & 15 & 7.7 \\
\hline Amount spent online during pandemic (in INR) & Total & 195 & \\
& Below 1000 & 28 & 15.6 \\
& $1001-2000$ & 39 & 21.7 \\
& $2001-3000$ & 54 & 30.0 \\
& $3001-4000$ & 22 & 12.2 \\
& $4001-5000$ & 24 & 13.3 \\
& Above 5000 & 13 & 7.2 \\
\hline Continue to shop online after the pandemic is over & Total & 180 & \\
\hline
\end{tabular}

Source: Survey Results

Table 2 indicate that out of the total number of respondent's majority (78.5\%) have online shopping experience before the pandemic hit the world. This percentage increased during the pandemic to $92.3 \%$. This supports the findings of the previous studies that customers are shifting their purchases to the online marketplaces during the pandemic. The respondents have reported spending more online during this period. Further, the data revealed that all the respondents who shopped online during the pandemic have shown interest to continue shopping online. Therefore, the study found that there is a change in the customer behaviour during the pandemic. 
Sahana Dinesh, and Dr. Y. MuniRaju

Table 3: Product Categories bought online during the COVID-19 era

\begin{tabular}{|c|c|c|c|}
\hline Product Category & Frequency & $\begin{array}{c}\text { Percentage based on } \\
\text { answers }\end{array}$ & $\begin{array}{c}\text { Percentage based on number of } \\
\text { respondents }\end{array}$ \\
\hline Consumer Electronics & 45 & 11.9 & 21.5 \\
\hline Clothing and Apparels & 48 & 12.7 & 22.9 \\
\hline Home and Kitchen Essentials & 82 & 21.8 & 39.2 \\
\hline $\begin{array}{c}\text { Personal and Health Care } \\
\text { Products }\end{array}$ & 72 & 19.1 & 34.4 \\
\hline Grocery & 68 & 18.0 & 32.5 \\
\hline Books & 34 & 9.0 & 16.2 \\
\hline Other products & 28 & 7.4 & 13.4 \\
\hline & 377 & 100.0 & 180.0 \\
\hline
\end{tabular}

Source: Survey Results

Note: N=180; Multiple Response Rate (MRR)=377/180=2.09

Table 3 highlights the products bought by the respondents online during the COVID-19 period. The table 2 revealed that 180 of 195 respondents have purchased online during the pandemic. The respondents were asked to check out the various products bought by them. Accordingly, 180 respondents have checked a total of 377 boxes, which is almost 2 boxes per respondent (MRR=2.09). The most bought product category during the pandemic is found to be Home and Kitchen Essentials followed by Personal and Health Care Products. The restrictions imposed on the movement of people during the lockdown and need to maintain hygiene has caused a surge in the demand for home essentials and personal and health care products.

Table 4: Customer attitude towards online shopping during the COVID-19 era

\begin{tabular}{|c|c|c|}
\hline Particulars & Mean & Standard Deviation (SD) \\
\hline Frequency of online shopping increased during the pandemic & 3.58 & .740 \\
\hline Recommend online shopping to others & 3.70 & .827 \\
\hline Satisfied with the decision to buy online during the pandemic & 3.96 & .675 \\
\hline
\end{tabular}

Source: Survey Results

Table 4 revealed a positive attitude of customers towards online shopping during the pandemic period. The data revealed that the frequency of online shopping has increased during the pandemic with a mean value of 3.58 $(\mathrm{SD} \pm 0.740)$. The respondents also were positive in recommending online shopping to their friends and family with a mean of 3.70 ( $S D \pm 0.827$ ). To measure the satisfaction of customers who shopped online, respondents were asked to rate a 5-point Likert's scale where 5 being highly satisfied and 1 being highly dissatisfied. The data revealed that the satisfaction of the respondents was also high with a mean value of 3.96 (SD \pm 0.675$)$. The satisfaction of the respondents is also revealed by a high recommendation rate and increased shopping frequency.

\section{CONCLUSION AND SUGGESTIONS}

Online retailing has grown immensely over the years and there is enough headroom for further growth. COVID19 has caused the e-commerce market to penetrate further, owing to customer hesitation to shop from offline stores. Apprehensions regarding shopping from physical stores and restrictions on movement have forced customers to buy online during the pandemic. For consumers online retail gives access to a large assortment of goods and for sellers it gives an opportunity to reach a large geographical area with limited resources. The sales of e-commerce platforms have significantly grown comparatively to the pre-lockdown order volumes. The results show that more customers are buying kitchen essentials, personal care products and groceries online. The demand for essentials and hygiene products is increasing and the online platforms have to ensure that the customer demand is met effectively so that satisfied customers are retained. The finding that customers are gradually shifting their purchases online emphasises that online platforms have to focus on improving customer experience. This is because increasing sales is not enough to ensure growth in the long run. The online retailers in India will have to invest more in infrastructure and also look for profitable tie-ups with local retail stores. The major players in the e-commerce market in the 
country could possibly achieve this more easily. However, smaller ones would have to concentrate their energy and efforts in meeting the increasing consumer demand. Offline retail stores too would have to reinvent themselves to drive customers in the 'new normal' scenario. In countries like India, it is unlikely that online stores could completely replace offline stores. Therefore, the offline retailers will have to become smarter with the adoption of smart technologies. Online retailers too would require constant innovations and coming up with programs to increase customer engagement. In addition to this, the platforms have to ensure the safety and security of personal and financial details of customers shopping on their websites by adopting suitable monitoring measures. This would boost the confidence of both existing customers as well as first time users to make purchases online and in turn would enhance customer trust.

\section{SOURCES OF FUNDING}

The research was funded by the University Grants Commission (UGC) under the JRF scheme.

\section{CONFLICT OF INTEREST}

The author have declared that no competing interests exist.

\section{ACKNOWLEDGMENT}

This study was funded by University Grants Commission under the JRF scheme.

\section{REFERENCES}

[1] Amazon services. (n.d.). What is 'Local shops on Amazon? Retrieved from https://services.amazon.in/services/sell-on-amazon/local-shops.html

[2] Bain \& Company (2020). How India shops online. Retrieved from https://www.bain.com/globalassets/noindex/2020/bain_report_how_india_shops_online.pdf

[3] Halan, D. (March 25, 2020). Impact of COVID-19 on online shopping in India. Retrieved from https://retail.economictimes.indiatimes.com/re-tales/impact-of-covid-19-on-online-shopping-inindia/4115

[4] IBEF. (May, 2019). E-Commerce. Retrieved from https://www.ibef.org/download/E-Commerce_Report-May2019.pdf

[5] Poojary, T., \& Krishna, V. (July 9, 2020). How COVID-19 brought about the significance of e-commerce in India. Retrieved from https://yourstory.com/2020/07/covid-19-significance-ecommerce-india-onlineshopping?utm_pageloadtype=scroll

[6] UNCTAD. (2020). COVID-19 and E-Commerce: Impact on Businesses and Policy Responses. Retrieved from https://unctad.org/system/files/official-document/dtlstictinf2020d2_en.pdf 